Отримано: 05 листопада 2018 р.

Прорецензовано: 19 листопада 2018 р.

Прийнято до друку: 29 листопада 2018 р.

e-mail: jakub.robel@o2.pl

DOI: $10.25264 / 2311-5149-2018-11(39)-36-40$
Jakub Robel. Cooperation between the congress of local and regional authorities of Europe and the local and regional authorities of the member states. Наукові записки Національного університету «Острозька академія». Серія «Економіка» : науковий журнал. Острог : Вид-во НаУОА, грудень 2018. № 11(39). С. 36-40.

$U D K 33.012 .334$

JEL Classification. F15, F55, H19

dr Jakub Robel,

Wyższa Szkoła Ekonomii, Prawa i Nauk Medycznych im. prof Edwarda Lipińskiego w Kielcach

\title{
COOPERATION BETWEEN THE CONGRESS OF LOCAL AND REGIONAL AUTHORITIES OF EUROPE AND THE LOCAL AND REGIONAL AUTHORITIES OF THE MEMBER STATES
}

The article presents the institutions of Congress of Local and Regional Authorities of the Council of Europe. Its role is to promote local and regional democracy improve local and regional governance and strengthen authorities' self-government. To this end, it shall cooperate closely with the local and regional authorities of the Member States. CLRAE is a pan-European political assembly, the 636 members of which hold elective office representing over 200,000 authorities in 47 European states.

Key words: Congress of Local and Regional Authorities; local and regional democracy, Council of Europe, local and regional authorities.

д-р Якуб Робель,

Вища Школа Економіки, Права і Медичних Наук ім. проф. Едварда Ліпінського у Кєльцее

\section{СПІВПРАЦЯ МІЖ КОНГРЕСОМ МІСЦЕВОЇ ТА РЕГІОНАЛЬНОЇ ВЛАДИ І МІСЦЕВИМИ ТА РЕГІОНАЛЬНИМИ ОРГАНАМИ ВЛАДИ КРАЇН ЧЛЕНІВ}

У статті аналізується співпраия між Конгресом місцевих та регіональних влад Європи та Комітетом регіонів Європейського Союзу. Обидві організації зосереджені на питанні функціювання регіонів, структура управління якими залежить від ресурсів.

Ключові слова: Конгрес місиевих та регіональних влад, місиева та регіональна демократія, Рада Свропи, місцева та регіональна влада.

д-р Якуб Робель,

Высшая Школа Экономики, Права и Медицинских Наук им. проф. Эдварда Липиньского в Кельце

\section{СОТРУДНИЧЕСТВО МЕЖДУ КОНГРЕССОМ МЕСТНОЙ И РЕГИОНАЛЬНОЙ ВЛАСТИ И МЕСТНЫМИ И РЕГИОНАЛЬНЫМИ ОРГАНАМИ ВЛАСТИ СТРАН ЧЛЕНОВ}

В статье анализируется сотрудничество между Конгрессом местных и региональных властей Европы и Комитетом регионов Европейского Союза. Эти организации основное внимание уделяют проблеме функиионирования регионов, структура управления которыми зависит от ресурсов.

Ключевые слова: Конгресс местных и региональных властей, местной и региональной демократии, Совета Европы, местных и региональных властей.

The Council of Europe has always held the position that democracy at the local and regional level plays a paramount role. Ultimately, freedom is a matter of both local and state. Local councils must meet the needs of all Europeans, in cities and in villages, in central, peripheral and border regions. There is no doubt that the Council of Europe is perceived as an organization promoting democracy, the rule of law and human rights, but it should not be forgotten that it is also open to new challenges. Therefore, it was all the more important to create a Congress of Local and Regional Authorities and situate it among other bodies of the Council of Europe. The new challenge was to ensure the representation of local authorities and the effectiveness of local and regional self-governments.

Today, the Congress of Local and Regional Authorities is one of the crucial bodies of the European Council. It is the third pillar of the Organization and the most important body for local and regional representatives elected in Europe. This contributes to the promotion and recognition of the government as well as local and regional decentralization as a prerequisite and an integral part of democratic governance.

It is important that Congress develops a close dialogue with major institutional partners such as the Committee of Ministers and the Parliamentary Assembly. It is also necessary to develop synergies and good cooperation 
with various partners in the Council of Europe, such as the Venice Commission (European Commission for Democracy through Law).

The Congress of Local and Regional Authorities of Europe plays an important role in ensuring the participation of local and regional authorities in the process of European unification and in the work of the Council of Europe. Therefore, it has a significant contribution to the RE legislative process in the field of local self-government and regional cooperation.

The Council of Europe has always held the position that democracy at the local and regional level plays a paramount role. Ultimately, freedom is a matter of both local and state. Local governments must meet the needs of all Europeans ${ }^{1}$. Therefore, in the Congress's competence, in particular, it is the promotion of the development of local and regional democracy in Europe, as well as the strengthening of cross-border and interregional cooperation $^{2}$. To this end, Congress may make recommendations to the Committee of Ministers and to the Parliamentary Assembly3.

Due to the fact that the Congress of Local and Regional Authorities belongs to the young institutions, it found itself in a special situation of a propagator and guardian of previously created - and therefore outside - European conventions in his sphere of activity. Because the administrative division of individual member states is very diverse, Congress is trying to solve this problem.

The Congress deals with the political and social issues that arise before local and regional authorities, in particular local and regional autonomy, urban and rural development, environmental protection, culture, education, social services and health ${ }^{4}$. Therefore, it is a forum where local and regional representatives can discuss common problems and share experiences 5 .

Whenever serious problems arise in the functioning of local or regional democracy, Congress advises the Committee of Ministers and the Parliamentary Assembly of the Council of Europe and cooperates closely with national and international organizations.

Starting from 1990, the Congress of Local and Regional Authorities of Europe has observed local elections. It is connected with the conviction that without democratic and fair elections it is difficult to talk about real selfgovernment. Observation of local elections is all the more important because their quality directly affects the functioning of local communities. Observation decides on the implementation of the right to choose representatives and on the possibility of control and evaluation of their activities. And thus serves to strengthen the role of local self-government. In art. In art. Article 2 paragraph 1 the statute of the Congress of Local and Regional Authorities lists its other competences, such as:

- taking measures to ensure the participation of local and regional communities in the implementation of the idea of a united Europe;

- proposing proposals promoting local and regional self-government to the Committee of Ministers of the European Council;

- promoting a foreign cooperation between local and regional communities;

- close cooperation with the Committee of the Regions of the European Union to ensure complementarity of their activities ${ }^{6}$.

In addition, the tasks of the Congress include, among others: analysis and preparation of reports on the state of local and regional democracy in the Member States about the candidate countries based on the standards contained in the European Local Government Charter and the observation of local and regional elections.

The analysis shows that the activities of the Congress of Local and Regional Authorities of Europe should be understood very broadly and in a multifaceted manner. CLRAE devotes most of its time to preparing reports, recommendations and resolutions addressed to the Committee of Ministers and local and regional authorities.

CLRAE holds annual regular sessions in Strasbourg. They are attended by delegations from authorized European organizations representing local and regional governments from member states of the Council of Europe. With the consent of the Congress or its organs, delegations of local and regional authorities from non-member countries that use the status of "guest of honor" at the Parliamentary Assembly as well as observers representing

\footnotetext{
${ }^{1}$ Zob. G. Krawiec. Europejskie prawo administracyjne. Wolters Kluwer. Warszawa, 2009. S. 42.

${ }^{2}$ Por. A. Mirosławska. Współpraca transgraniczna jako czynnik rozwoju regionalnego. Zagadnienia Ekonomiki Rolnej. 2000, nr 6, s. 43-55.

${ }^{3}$ Zob. H. Izdebski. Rada Europy: organizacja demokratycznych państw Europy i jej znaczenie dla Polski, SCHOLAR, Warszawa, 1996. S. 57.

${ }^{4}$ Zob. T. Szewc. Dostosowanie prawa polskiego do zasad Europejskiej Karty Samorządu Terytorialnego. Oficyna Wydawnicza Branta. Bydgoszcz-Katowice, 2006. S. 19.

${ }^{5}$ Zob. M.E. Kamińska. Polityka regionalna Unii Europejskiej. Sprawy Międzynarodowe. 2001, nr 3, s. 85-102.

${ }^{6}$ Statutory Resolution. CM/Res (2011) 2 / Adopted by the Committee of Ministers, źródło. URL: http://wcd.coe.int, data dostępu: 03.09.2016.
} 
European local and regional government organizations may also participate. Congress organizes its work in two chambers: the Chamber of Local Authorities and the Chamber of Regions. Each of them has a number of seats equal to the number of seats in Congress. Sessions of the Chambers are held directly before or after the plenary sessions of the Congress. The Permanent Committee ensures continuity of work between plenary sessions.

In order to make CLRAE more efficient and flexible, both chambers may create small ad hoc working groups to analyze some of the problems. The Head of the Congress Secretariat, responsible for the management of current affairs, is assisted by the Council of Europe's officers.

After separating the problems between the two chambers and the statutory committee in accordance with the Presidium of the chamber to which a given responsibility belongs, it can create, by way of exception, an ad hoc working group consisting of a limited number of members - up to eleven, equipped with a detailed mandate - preparation of a report, organization of conferences, monitoring of cooperation projects or specific intergovernmental activities of the Council of Europe. If the above-mentioned issue belongs simultaneously to the competences of both chambers, the Presidium of the Congress of Local and Regional Authorities of Europe may create, by way of exception, an ad hoc working group common to both chambers.

The essential work on the Congress's documents and initiatives takes place in working groups. For example, the Group of independent experts on the European Charter of Local Self-government gathers competent experts in legal, political or financial fields specializing in issues related to local and regional democracy. The Group assists the three statutory committees with performing their tasks under the Statute, in particular with regard to the preparation of reports on the situation of local and regional democracy in the case of states that are the subject of activities undertaken following the adoption of the Charter. In this sense, the basic task of the groups is to provide legal assistance to Congress in its political mission ${ }^{7}$. Since the beginning of CLRAE, the number and composition of working groups has changed frequently. For example, there were previously twenty specialized groups grouped into four categories: subordinate to the Chamber of Local Authorities, the Chamber of Regions, both Houses or so-called twin working groups.

Through the observation (monitoring) missions, CLRAE conducts audit visits in all RE Member States, reviewing compliance with the principles contained in the European Local Government Charter. One of the priorities of the Congress's activities is also the observation of local elections. This activity complements the political monitoring of the European Charter of Local Self-government, which is the foundation of local democracy in Europe.

After each visit, a final report is presented. It usually includes chapters on election observation or evaluation of the implementation of the provisions of the Charter, a description of legal grounds, conclusions and post-audit recommendations.

The final report is usually presented at a press conference and also placed on the website of an international organization.

Congress also conducts consultations, for example. among organizations representing European mountain regions and is a co-organizer of numerous conferences.

The communication policy of the Congress, which is addressed to various target groups, also plays a essential role. On the one hand, it is a service for citizens and the media, immediately informing them of changes that affect them. On the other hand, it is a service for local and regional authorities and their associations, informing them directly about the activities of the Congress and the documents that cover their activities. The goal is to create clear, concise and relevant messages for each target group based on the communication strategy.

Effective Congress activities would not have been possible without the appropriate financial outlays to achieve its goals. The budget or its constraint largely affects both the forms in which Congress decides to work and their effectiveness ${ }^{8}$.

The organization of territorial administration of member states of the Council of Europe is very diverse. One of the reasons for this is that some Member States have a federal system or have adopted a regional model that is approaching federalism, or are unitary states. This is also due to the diversity of the administrative system in these countries. In particular, there are differences - not necessarily related to the size of the state - in the number of levels of territorial authorities, as well as in the number of levels in which local government was organized? In any event, during the creation of the Congress, the importance of organizing regional issues was stressed - all

\footnotetext{
${ }^{7}$ Zob. Group of Independent Experts on the European Charter of Local Self-Government, źródło. URL: http://www.coe.int/t/ congress/system/submenucontents_en.htm (Data dostępu: 17.10.2018).

${ }^{8}$ Por. Recommendation 393 (2017) of The Congress of Local and Regional Authorities, The budget and resources of the Congress for the next biennium (2018-2019) / Debated and adopted by the Congress on 28 March 2017, 1 st sitting (Doc. CG32(2017)06, explanatory memorandum).

${ }^{9}$ Zob. H. Izdebski. Współczesne modele administracji publicznej, Urząd Rady Ministrów. Warszawa, 1993. S. 78.
} 
the more so because the European Union already had the Committee of the Regions being the guardian of the interests of representatives of regions at the level of the European Union ${ }^{10}$.

Cooperation of the Congress with the local and regional authorities of the member states of the Council of Europe requires creating a common ground that would allow for the same understanding of basic concepts, to set common goals and standards and common criteria for assessing the phenomena. Without such a platform, cooperation is simply impossible. For this purpose, Congress conducts a constructive dialogue with the governments of the Member States and encourages them to involve local and regional authorities more widely in the decision-making process and assesses compliance with the principle of subsidiarity ${ }^{11}$.

This cooperation requires that institutions and forms of action in the Member States meet the same principles and criteria. According to J. Regulski, this aim is served by the conventions of the Council of Europe, and in the field of local democracy, primarily by the European Charter of Local Self-Government. The set of principles contained therein is a guideline, indicating the constitutional principles that each country should fulfill in order to be able to say that its system is democratic and decentralized.

The basis for this cooperation is undoubtedly the attempt by Congress to ensure the participation of local and regional authorities in the process of European unification as well as in the work of the Council of Europe. It manifests itself in the promotion of the development of local and regional democracy in Europe as well as the strengthening of cross-border and inter-regional cooperation. To this end, Congress has the right to make recommendations to the Committee of Ministers and to the Parliamentary Assembly.

The literature emphasizes that the intention of the Congress is to play in the Council of Europe, in parallel to the Parliamentary Assembly, the role of the "upper house", or in other words the Senate, representing all European regions equally. At the same time, within the Congress there are tendencies to give more weight to the institutionally stronger regions enjoying greater autonomy and scope of competence ${ }^{12}$.

In the sense of the Congress, regional authorities, with the exception of justified state intervention, should have their own competences, freedom of decision making, democratic structures, as well as adequate personnel and financial resources.

Local and regional authorities are therefore an important part of the democratic system in Europe ${ }^{13}$. That is why there is so much interest on the part of the Council of Europe, which, after all, defends democracy and human rights. According to the Council of Europe, the region should enjoy a guarantee of self-government, preferably contained in constitutional norms and, thanks to a council coming from direct elections and executive bodies responsible for it, be able to deal with a significant part of public affairs. The region should decide its own management structure, be subject to interference by other authorities only to ensure respect for the law, have its own appropriate resources at its disposal within his scope of responsibility, freedom of association and appeal to the court ${ }^{14}$.

CLRAE has repeatedly stated in its reports that elected representatives make decisions close to the people they represent. However, although the sector has its own democratic legitimacy, it operates within the state framework as well as in the overall economic context. It faces big challenges when the growing public demand for more and better services encounters large and resource constraints - which may intensify the phenomenon of the economic crisis. These tensions have a direct impact on service providers - employees.

In conclusion, it should be stressed that Congress is an important driving force in promoting the concept that local and regional authorities should have the power to manage their own affairs under the relevant national legislation. In this respect, Congress also influenced the development in the new member states from Central and Eastern Europe and those who are waiting for membership in the Council. In fact, the LODE (Local Democracy) program is considered to be remarkably successful ${ }^{15}$.

\section{Bibliography:}

1. Balcerowska A. Regiony w europejskiej przestrzeni prawnej. Samorzad Terytorialny. 1999, nr 7-8.

2. Izdebski H. Rada Europy: organizacja demokratycznych państw Europy i jej znaczenie dla Polski. SCHOLAR, Warszawa, 1996.

3. Kamińska M. E. Polityka regionalna Unii Europejskiej. Sprawy Międzynarodowe. 2001, nr 3.

\footnotetext{
${ }^{10}$ Zob. A. Sobolewski. Regiony i polityka regionalna Unii Europejskiej - aspekty prawne i formalne. Studia i Materiały Miscellanea Oeconomicae. 2010, nr 2. S. 155.

${ }^{11}$ Zob. H. Klebes. Subsydiarność w pracach Rady Europy i jej relacjach z Unią Europejską. Subsydiarność / red. D. Milczarek, Centrum Europejskie Uniwersytetu Warszawskiego. Warszawa, 1996. S. 54-55.

${ }^{12}$ Zob. A. Balcerowska. Regiony w europejskiej przestrzeni prawnej. Samorząd Terytorialny. 1999, nr 7-8. S. 48.

${ }^{13}$ Por. Le droit de vote Individual des femmes: une exigence democratique. Conseil de I"Europe. Strasbourg, 2002.

${ }^{14}$ Zob. A. Balcerowska. Regiony w europejskiej .... S. 49.

${ }^{15}$ Zob. H. Klebes. Zasada subsydiarności w pracach Rady Europy jej relacjach z Unią Europejską. Subsydiarność / red. D. Milczarek, Centrum Europejskie Uniwersytetu Warszawskiego. Warszawa, 1998. S. 54.
} 
4. Klebes H. Subsydiarność w pracach Rady Europy i jej relacjach z Unią Europejską. Subsydiarność / red. D. Milczarek, Centrum Europejskie Uniwersytetu Warszawskiego. Warszawa, 1996.

5. Krawiec G. Europejskie prawo administracyjne, Wolters Kluwer. Warszawa, 2009.

Le droit de vote Individual des femmes: une exigence democratique, Conseil de I"Europe, Strasbourg, 2002.

6. Mirosławska A. Współpraca transgraniczna jako czynnik rozwoju regionalnego. Zagadnienia Ekonomiki Rolnej. 2000, nr 6.

7. Szewc T. Dostosowanie prawa polskiego do zasad Europejskiej Karty Samorzadu Terytorialnego. Oficyna Wydawnicza Branta. Bydgoszcz-Katowice, 2006.

8. Statutory Resolution CM/Res (2011) 2 / Adopted by the Committee of Ministers, źródło. URL: http://wcd.coe. int (Data dostępu: 03.09.2016).

9. Sobolewski A. Regiony i polityka regionalna Unii Europejskiej - aspekty prawne i formalne. Studia i Materiaty Miscellanea Oeconomicae. 2010, nr 2. 